\title{
Adaptation to Climate Changes with Particular Focus on the Legal Environment of the Energy Sector
}

\section{Adaptation to climate changes - the neglected sister of mitigation of climate changes}

Climate policy in general seems to be based on two cornerstones: mitigation of and adaptation to climate changes. While the meaning of the first one seems evident (as mitigation of climate changes is actually implemented by reducing anthropogenic emissions of greenhouse gases, in particular carbon dioxide), adaptation consists in a variety of miscellaneous actions and lacks a uniform definition. Some researchers say that adaptation means "adjusting to the unavoidable impacts of anthropogenic and natural climate change", underlining that climate changes have divergent origins, but all their impacts require adaptation. ${ }^{1}$ Others indicate that apart from adjustment to negative ramifications of climate changes, adaptation comprises also a second angle of taking advantage of any possible benefits climate changes may bring. ${ }^{2}$ The two aforementioned facets of climate policy, mitigation and adaptation, may be balanced in different ways. Still, there are many doubts as to what relations between mitigation and adaptation should be set forth, i.e. how those two angles should be balanced with regard to each other.

At the point where the story of combating climate changes begins, i.e. at the international level, adaptation to climate changes has usually seemed, at least as far as law in books is concerned, to be of equal importance to their mitigation. As is noticed in legal doctrine, ${ }^{3}$ in the convention on climate change of $1992,{ }^{4}$ mitigation and adapta-

1 R. Biesbroek, A. Lesnikowski, Adaptation."The Neglected Dimension of Polycentric Climate Governance?" [in:] Governing Climate Change: Polycentricity in Action?, eds A. Jordan et al., Cambridge 2018, p. 307.

2 S. Agrawala et al., "Adapting to Climate Change: Costs, Benefits, and Modelling Approaches", International Review of Environmental and Resource Economics 5/2011, p. 246.

3 J. Verschuuren, "Legal Aspects of Climate Change Adaptation" [in:] Climate Change and the Law, eds E.J. Hollo et al., Dordrecht 2013, p. 258.

4 United Nations Framework Convention on Climate Change of 1992 (UNFCCC), https://unfccc.int/ resource/docs/convkp/conveng.pdf [accessed: 2021.01.01]. 
tion were considered as two equally important and concurrent paths to be followed. Not only do several points in article 4 of the convention clearly refer to commitments of signatories with regard to adaptation, but also article 2, enshrining the main objective of the convention, invokes and suggests even the prevalence of adaptation over mitigation. The provision in question states that the ultimate goal of the convention and any related acts is "stabilization of greenhouse gas concentrations in the atmosphere at a level that would prevent dangerous anthropogenic interference with the climate system. Such a level should be achieved within a time frame sufficient to allow ecosystems to adapt naturally to climate change (...)". It should be pointed out that there seems to be a correlation between such a standpoint of the convention, granting a similar degree of attention to mitigation and adaptation, and recognition as the principal objective the stabilization (and not the reduction) of greenhouse gas levels in the atmosphere. The self-restraining wording of the provision in that respect is in harmony with devoting at least as much attention to adaptation as was devoted to mitigation. In other words, should impacts of climate changes be looked at as not so serious and uncertain, adaptation may even outweigh mitigation actions, since the aim is limited to keeping greenhouse gas concentrations in the atmosphere as they are at that point.

And, as the paradigm shift since the Kyoto Protocol of $1998^{5}$ shows, vice versa; the more risks related to climate changes are perceived as gross and imminent, the greater emphasis is put on mitigation and the less attention is received by adaptation, because it is deemed necessary to tend toward reduction, and not only stabilization of greenhouse gases emissions. The Kyoto Protocol almost completely abandoned adaptation rhetoric and focused on mitigation, which is not surprising, since the principal objective underlined in many provisions of that act is reduction, and not stabilization of greenhouse gases emissions. Although at the international level there have existed various funds aimed at financing adaptive actions of developing countries, further treaties went the same path, putting mitigation first and including only minor references to adaptation. For instance, the Paris Agreement of $2015^{6}$ relies predominantly on nationally determined contributions to global emissions reduction.

The drawback of such dependency that has appeared, thus, is the fruit of pride and vanity; human kind is, in fact, not omnipotent and is not capable of preventing any and all degrees of climate changes from occurring - even if all conceivable measures, onerous and costly though they may be, are fully implemented by the entire world in pursuit of an enormous reduction of anthropogenic greenhouse gases emissions. It is worth quoting professor R. Lindzen here, who states: "Now here is the currently popular narrative concerning this system. The climate, a complex multifactor system, can be summarized in just one variable, the globally averaged temperature change, and is primarily controlled by the $1-2 \%$ perturbation in the energy budget due to a single

\footnotetext{
5 Kyoto Protocol to the United Nations Framework Convention on Climate Change of 1998, https:// unfccc.int/resource/docs/convkp/kpeng.pdf [accessed: 2021.01.01].

6 Paris Agreement of 2015, https://unfccc.int/sites/default/files/english_paris_agreement.pdf [accessed: 2021.01.01].
} 
variable - carbon dioxide - among many variables of comparable importance. This is an extraordinary pair of claims based on reasoning that borders on magical thinking. It is, however, the narrative that has been widely accepted, even among many sceptics (...) Many politicians and learned societies go even further: They endorse carbon dioxide as the controlling variable, and although mankind's $\mathrm{CO}_{2}$ contributions are small compared to the much larger but uncertain natural exchanges with both the oceans and the biosphere, they are confident that they know precisely what policies to implement in order to control carbon dioxide levels". ' So the error is twofold here; first, science has not fully understood yet the wide array of intra- and interrelations that climate is involved in, where the level of anthropogenic greenhouse gases emissions is only one of many different factors; and secondly, although anthropogenic greenhouse gases emissions could have some negative influence on climate changes, they are not so great as to be a key circumstance. Therefore, even massive reduction of greenhouse gases emission will not prevent climate changes from taking place. The most we can do (assuming that worldwide, concerted actions are successfully implemented and result in a great reduction of emissions) is to alleviate (probably slightly) the negative dimension of climate changes. Leaving aside the question of the connection between human actions and climate change (both in its negative and positive aspect), we have a problem at the stage of attaining any significant global emission reduction. As is estimated in research, achievement of the European Union goal of reducing greenhouse gases emissions by $20 \%$ (or $30 \%$, under some circumstances) up to the year 2020 (as juxtaposed to levels from 1990) may bring a global reduction of less than $4 \% .{ }^{8}$ And, as is clearly visible, the European Union has been by far the most ambitions entity and front runner in terms of climate policy. Thus, bearing in mind that for many reasons mitigation will certainly not entail preventing climate changes from happening, more attention should be paid to adaptation actions.

Adaptation has never been especially advocated at the level of EU law, so the mistake in question appeared from the start. Stepping down from the international legal order to the level of EU law, as well as to the domestic legal orders of EU Member States, we clearly see that the discrepancy between the space and means devoted to mitigation, on the one hand, and the space and means devoted to adaptation, on the other hand, has been growing wider and wider, obviously to the detriment of adaptation. There is only a relatively modest number of documents intended to ensure implementation of adaptation actions. An example of EU soft law concerning adaptation is the EU Strategy on adaptation to climate change of $2013 .{ }^{9}$ Adaptation is assessed there as an indispensable, although costly path. The rough estimate provided in the docu-

\footnotetext{
7 https://www.thegwpf.org/content/uploads/2018/10/Lindzen-2018-GWPF-Lecture.pdf [accessed: 2021.01.01].

8 V. Termini, "Energy and European Institutions" [in:] The European Union in the 21st century: perspectives from the Lisbon Treaty, eds S. Micossi, G.L. Tosato, Brussels 2009, p. 116.

9 Communication from the Commission to the European Parliament, the Council, the European Economic and Social Committee and the Committee of the Regions - An EU Strategy on adaptation to climate change, $\operatorname{COM}(2013) 216$ final.
} 
ment states that "the minimum cost of not adapting to climate change is estimated to range from $€ 100$ billion a year in 2020 to $€ 250$ billion in 2050 for the EU as a whole.". ${ }^{10}$ However, the aforementioned text is not legally binding and even within the domain of soft law, it is a rather isolated example of a document dealing with adaptation to climate changes, very vague in its wording and, actually, not entailing any real effects. More concrete, although also not a legally binding EU document, the Energy Roadmap 2050 of $2011^{11}$ hardly ever mentions adaptation, while repeatedly invoking decarbonisation and other possibilities of greenhouse gases emissions reduction.

The situation is not better, at least in terms of express references to adaptation, when it comes to the law of the European Union. In terms of treaties, article 191.1 $\mathrm{TFEU}^{12}$ recognizes "promoting measures at international level to deal with regional or worldwide environmental problems, and in particular combating climate change" as one of the principal objectives of EU environmental policy. By using the expression "combating climate change", the legislator clearly puts an emphasis on mitigation, not adaptation (not to mention any doubts one might have as to whether human beings could actually be "combating climate change" and whether it is rational to do so). Furthermore, there is no act of secondary EU law that is devoted to adaptation to climate changes. Instead, some references to adaptation may be found in various directives and regulations within the framework of EU climate policy. For instance, in the directive setting forth the rules of the EU emissions trading scheme, ${ }^{13}$ article 10.3 letter (a) mentions adaptation as one of the climate-related purposes on which at least $50 \%$ of revenues from auctioning emissions allowances should be spent. However, adaptation is still mentioned after emissions reduction here. Similarly, adaptation purposes are referred to in the so-called Taxonomy Regulation ${ }^{14}$, in light of which climate change adaptation is one of the qualified environmental objectives; so if an economic activity contributes substantially to such a purpose, it may be deemed an environmentally sustainable investment eligible for financing, according to the regulation. ${ }^{15}$ Recital 25 of the regulation explains further that "an economic activity that pursues the environmental objective of climate change adaptation should contribute substantially to reducing or preventing the adverse impact of the current or expected future

10 Ibidem, p. 3.

11 Communication from the Commission to the European Parliament, the Council, the European Economic and Social Committee and the Committee of the Regions - Energy Roadmap 2050, COM(2011) 885 final.

12 Consolidated version of the Treaty on the Functioning of the European Union, OJ C 326 of 26.10.2012, p. 47-390.

13 Directive 2003/87/EC of the European Parliament and of the Council of 13 October 2003 establishing a scheme for greenhouse gas emission allowance trading within the Community and amending Council Directive 96/61/EC, OJ L 275 of 25.10.2003, p. 32-46, as amended.

14 Regulation (EU) 2020/852 of the European Parliament and of the Council of 18 June 2020 on the establishment of a framework to facilitate sustainable investment, and amending Regulation (EU) 2019/2088, OJ L 198 of 22.6.2020, p. 13-43.

15 See A. Sikora, European Green Deal - legal and financial challenges of the climate change, ERA Forum 2021, vol. 21. 
climate, or the risks of such adverse impact, whether to that activity itself or to people, nature or assets" - from which a definition of adaptation itself could be derived. Thus, although adaptation is mentioned in the law of the European Union, mitigation clearly outweighs it both in terms of quantity and quality. References to adaptation in EU law are rather ancillary and the vast majority of climate protection legislation is focused on emissions reduction efforts.

As the climate policy of Poland is obviously the aftermath of the climate policy of the $\mathrm{EU}$, the domestic situation there is similar. Adaptation is rarely invoked in national law as compared to mitigation. There is no legal act the subject of which is adaptation to climate change. However, there is a soft law document - the Polish National Strategy for Adaptation to Climate Change, ${ }^{16}$ consisting of detailed analysis of foreseeable impacts of climate changes on various aspects of life and economy in Poland, as well as action plans for relevant sectors. That document also presents high values of estimated adaptation costs, stating: "Forecasts in Europe invoked by the European Environment Agency predict spending of several billion EUR a year in the short term and tens of billions in the long term. Despite the differences in available estimates of costs at the global, EU and individual country level, the authors of analyses agree that the possible discontinuance of adaptation actions will result in even greater losses".17 The large sums that need to be allocated for adaptation to climate changes are also mentioned in economic literature. It is foreseen that costs of adaptation will be high and will get higher and higher in time, since "adaptation cost estimates from the more recent studies range from around $\$ 25$ billion a year to well over $\$ 100$ billion for the next two decades. The wide range is symptomatic for the poor state of knowledge. Estimates remain indicative and incomplete. The numbers refer to the annual cost of adapting to 'median' climate change over the next 20 years. Adaptation costs are likely to grow further over the longer term as the impacts of climate change are increasingly felt" ${ }^{\prime 18}$. At the same time, it is noticed that "cost-effective adaptation is unlikely to reduce impacts to zero. There will be substantial residual damages that adaptation cannot avoid". ${ }^{19}$

However, all the aforementioned considerations demonstrate that forcing mitigation while omitting adaptation is a serious mistake that may (and probably will) take its toll in the future, irrespective of the standpoint we adopt towards the dogma that climate changes are in a direct causal link with anthropogenic emissions of greenhouse gases, and that the latter are of crucial importance in producing the former. Actually, irrespective of all climatology issues, there is an urgent need to address adaptation to climate changes as an indispensable way of diminishing severe ramifications. A re-

\footnotetext{
16 Polish National Strategy for Adaptation to Climate Change (NAS 2020) with the perspective by 2030, https://klimada.mos.gov.pl/wp-content/uploads/2014/12/ENG_SPA2020_final.pdf [accessed: 2021.01.01].

17 lbidem, p. 5.

18 S. Fankhauser, "The Costs of Adaptation", Wiley Interdisciplinary Reviews: Climate Change 1/2010, s. 27.

19 Ibidem, p. 24.
} 
view of economic studies of mitigation and adaptation performed by S. Agrawala et al. suggests that applying a blend of mitigation and adaptation actions would yield the greatest benefits. However, at the same time they note that the increased level of adaptation entails diminution of the marginal benefit of mitigation, the aftermath of which may be rise of emissions in the future. ${ }^{20}$

Such a rise of emissions that may, quite ironically, be effectuated by climate policy resulting in increased exploitation and use of fossil fuels ${ }^{21}$ is often discussed as socalled "green paradox". That notion is used in a general manner to denominate undesired effects of climate policy, in the form of deepening environmental problems. Such problems are that, because of climate policy, entities interested in exploiting fossil fuels will intensify their exploitation and use, because of the danger to a part of their income (a scarcity rent) related to a decision when and to what extent one should take advantage of conventional resources (the so-called weak green paradox). Furthermore, if entities exploiting fossil fuels despite climate policy are capable of exploiting nearly all resources making profit, postponing exploitation may increase total damages (the so-called strong green paradox). ${ }^{22}$ Nationally determined, voluntary contributions to emissions reduction under the Paris Agreement seem to be a perfect example of the green paradox incarnated; some developing countries have declared that at present they will not decrease greenhouse gases emissions, but increase them further, only trying to reach the peak as soon as possible.

The analysis of traces of adaptation in the international, EU and domestic legal orders makes it possible to draw a conclusion that adaptation seems to be a neglected sister of mitigation. To some extent, such a situation may be explained by invoking the different natures of mitigation and adaptation. In contrast to mitigation, adaptation actions are considered to be "depoliticised and technocratic in most instances". ${ }^{23}$ Therefore, most adaptation "is thus guided by procedural rules - for example, the requirement to have a local adaptation strategy or specific considerations of adaptation in impact assessments - rather than substantive rules of specific goals and targets to be achieved"24.

Also, as J. Verschuuren observes, "whereas mitigation measures primarily can be implemented in one policy field (that of environmental law), adaptation measures have to be implemented through a wide range of policies such as water, marine and coastal, fisheries, biodiversity, energy, building and construction, agriculture, telecommunications, infrastructure, etc.". ${ }^{25}$ Therefore, adaptation is more difficult to be involved in le-

\footnotetext{
20 Ibidem, passim.

21 F. van der Ploeg, C. Withagen, "Global Warming and the Green Paradox: A Review of Adverse Effects of Climate Policies", Review of Environmental Economics and Policy 2015, vol. 9, issue 2, p. 300.

22 S. Jensen et al., "An Introduction to the Green Paradox: The Unintended Consequences of Climate Policies", Review of Environmental Economics and Policy 2015, vol. 9, issue 2, pp. 246-247.

23 R. Biesbroek, A. Lesnikowski, Adaptation..., p. 307; see also I. Burton, R.W. Kates, G.F. White, The Environment as Hazard, New York 1978, p. 41-42 after: T.J. Bassett, Ch. Fogelman, “Déjà vu or Something New? The Adaptation Concept in the Climate Change Literature", Geoforum 2013, vol. 48, p. 44.

24 R. Biesbroek, A. Lesnikowski, Adaptation..., p. 315.

25 J. Verschuuren, Legal Aspects..., p. 258.
} 
gal provisions than mitigation, and rarely would there appear in legal acts direct references to adaptation to climate changes. Moreover, which is of particular significance in the case of international and EU law, "mitigation can assessed using a single global metric_-GHG emissions (GHG) - representing a common global burden. This allows a scientific definition of policy goals and the quantitative analysis of progress, from global to national level. It is therefore possible to translate the results of global studies into policy targets. In contrast, adaptation is concerned with impacts, which are often local in nature, and there are no common physical metrics to assess aggregated impacts or adaptation responses. This makes it extremely different to set global targets and measure progress". ${ }^{26}$ Generally, adaptation fits better in the national legal agendas than in broader legal orders, because "benefits of adaptation actions primarily accrue to those who undertake the measures, and are therefore appropriable"27 (alas, that is not the case in mitigation, where lack of global ambitious actions predetermines the failure of unilateral steps to reduce anthropogenic greenhouse gases emissions adequately in order to eliminate climate changes, and where, at the same time, the presence of such global ambitious actions is far from guaranteeing success). Therefore, it is suggested that adaptation does not necessarily have to be regulated in international and EU law, and that apart from provision of financial and technical support to facilitate adaptation, it should be coordinated at the international level. ${ }^{28}$ It should also be emphasized that different countries face different circumstances resulting from climate changes; so there is no universal technique of adaptation, and although there are some similarities that may be perceived in various economic sectors, adaptation actions have to be tailored to miscellaneous variables appearing in particular countries. That is in harmony with the remark from the European Commission's White Paper - Adapting to Climate Change: Towards a European Framework for Action of 2009, ${ }^{29}$ which reads as follows: "Due to the regional variability and severity of climate impact most adaptation measures will be taken at national, regional or local level. However these measures can be supported and strengthened by an integrated and coordinated approach at EU level".

Nonetheless, these observations do not provide a full picture. As has been justly pointed out by researchers, adaptation was - and in my opinion still is - "considered to be further down the political agenda - a distraction from the more urgent issue of avoiding the problem in the first place via taking mitigating actions". ${ }^{30}$ Clearly, in consideration of the already mentioned factors justifying the attention and care that ought to be devoted to adaptation, such an approach should be corrected.

\footnotetext{
26 P. Watkiss et al., "The Complementarity and Comparability of Climate Change Adaptation and Climate Change Mitigation", Wiley Interdisciplinary Reviews: Climate Change 6/2015, p. 548.

27 S. Agrawala et al., Adapting to Climate Change..., p. 247.

28 Ibidem, p. 248.

29 White paper - Adapting to climate change: towards a European framework for action \{SEC(2009) 386\} \{SEC(2009) 387\} \{SEC(2009) 388\}, COM/2009/0147 final.

30 R. Biesbroek, A. Lesnikowski, Adaptation..., p. 303.
} 
Balancing mitigation and adaptation could pose some problems in terms of the proper setting of those two facets with regard to each other - which is expressly noticed neither in the international legal order, nor in the law of the European Union. Namely, mitigation and adaptation could sometimes be mutually reinforcing, but from time to time they could act to the detriment of each other. Quite surprisingly, a mention on that matter is found in the Polish National Strategy for Adaptation to Climate Change, which states the following: "Some of adaptation actions carried out in one area may deteriorate the effectiveness of actions in another area, for example an increase in the use of air-conditioning units or larger production of artificial snow for ski slopes contributing to increased consumption of energy and water. In turn, the developed cultivation of energy crops and biomass may limit the availability of water resources". Also in the literature we find examples of such disadvantageous relations between mitigation and adaptation, for instance those claiming that mitigation policies could shift the energy generation mix toward more water-dependent technologies (like carbon capture and storage - CCS), in which case any consequences of climate changes would more possibly curb mitigation efforts. ${ }^{31}$ Such situations call for application of the theory developed within the framework of the integrated protection principle. According to its authors, the factual states covered by the principle fall within two distinct categories: a model of the divergent principle of integrated protection and a model of the convergent principle of integrated protection. While the latter consists of situations where the goals pursued are of such character that can easily be achieved simultaneously, the first one includes cases where the aims are conflicting. ${ }^{32}$ Here appears another question: does the integrated protection principle imply that in the event of contradiction existing between aims directed towards environmental protection and other objectives, priority should be attributed to the first category? Legal doctrine puts an emphasis on the necessity of balancing aims to find an equilibrium that would make it possible to achieve all the aims to the proper extent. ${ }^{33}$ In practice, however, that issue has to be resolved on a case-by-case basis. Just as when balancing mitigation and adaptation, one would say.

\section{Ramifications of climate changes with regard to the energy sector}

As has already been mentioned, whatever the results of mitigation efforts may be, some impacts of climate changes seem to be inevitable, and therefore, some degree of adaptation actions will certainly be necessary. That is especially true in the case of

\footnotetext{
31 J.C. Ciscar, P. Dowling, "Integrated Assessment of Climate Impacts and Adaptation in the Energy Sector", Energy Economics 2014, vol. 46, p. 532.

32 R. Breuer, "Umweltschutzrecht" [in:] Besonderes Verwaltungsrecht, ed. E. Schmidt-Assmann, Berlin - New York 1995, after: P. Korzeniowski, Zasady prawne ochrony środowiska, Łódź 2010, p. 340.

33 A. Wasilewski, "Koncepcja zintegrowanej ochrony środowiska w prawie Wspólnoty Europejskiej" [in:] Studia z prawa Unii Europejskiej w piątą rocznicę utworzenia Katedry Prawa Europejskiego Uniwersytetu Jagiellońskiego, ed. S. Biernat, Kraków 2000, p. 513.
} 
the energy sector which has a crucial role for the entire economy; if proper functioning of any element of that sector is put in jeopardy by climate changes, negative consequences will appear in various economic sectors as side effects. For instance, competition for water resources (in electricity generation, oil refining and irrigation of energy crops) and land competition (for biofuels production) are identified as two main crosssector impacts of climate change, related to the functioning of the energy sector. ${ }^{34}$ But first, more generally, the pressures that climate impacts may exert on the energy sector will spill over and disturb the proper functioning of other economic branches, since energy is a crucial and indispensable input that has to be invested to manufacture goods and provide services. That is why the energy sector, in the context of its adaptation to climate changes, deserves special attention among many other economic segments.

At the same time, according to research, "the energy system indeed may be one of the sectors of the economy potentially most affected by climate change".35 It should also be pointed out that the sector in question will be affected by climate changes on a global dimension, everywhere in the world - although such influence may be of a different nature in different places.

An interesting remark that may be made here is that a consideration of the impacts of climate changes on the energy sector could also bring in the potential advantages of climate changes. As the EU Strategy on adaptation to climate change of 2013 states: "Global warming may provide opportunities for specific sectors in certain areas, such as (...) more hydropower or less energy needed for heating in northern Europe". Also in the literature, apart from threats posed by climate changes to the energy sector, some authors perceive potential chances for that sector. For instance, J. Verschuuren observes that "there are several opportunities as well, such as a higher potential for wind energy as well as for solar energy, whereas the overall demand in energy in a large parts of the world will decrease because of milder winters". ${ }^{\prime 36}$

Nevertheless, the vast majority of studies indicate that "the adaptation costs of increased cooling will be greater than the benefits associated with reduced heating demands". ${ }^{37}$ Such a conclusion may be extrapolated to all ramifications of climate changes with regard to the energy sector, but also outside that sector. Although estimations are rough due to a lack of scientific certainty, it clearly seems that the drawbacks of climate changes will outweigh, by far, advantages that may result, both in terms of particular territories and the whole world.

Effects of climate changes with regard to the energy sector will be very extensive, spreading through all components of the energy chain, such as exploitation of energy resources and energy production, energy transmission and distribution (through impacts on the energy infrastructure), as well as energy use and consumption. The broad

34 R. Schaeffer et al., "Energy Sector Vulnerability to Climate Change: A Review", Energy 1/2012, p. 9.

35 J.C. Ciscar, P. Dowling, Integrated Assessment..., p. 531.

36 J.Verschuuren, Legal Aspects..., p. 281.

37 S. Agrawala et al., Adapting to Climate Change..., p. 257. 
scope of such effects, jointly with the position of energy carriers as strategic resources, indispensable for the economy, with no substitute available, ${ }^{38}$ as well as the crucial functions that the energy sector plays, highlight the importance of the adaptation of that branch. As is noticed by researchers, "climate induced impacts in the energy sector are likely to resonate widely throughout the rest of the economy as energy is a key input to many other sectors". ${ }^{39}$

The vulnerability of the energy sector to impacts of climate changes originates from the great influence changes in temperature and water availability have on its functioning. ${ }^{40}$ An analysis of the aforementioned segments of the energy sector that could be affected by climate changes is worth making, dealing in turn with each area.

As for the exploitation of energy resources and production of energy, the consequences of climate changes will definitely be multidimensional. First, climate changes may influence the amount and accessibility of energy carriers. This pertains both to fossil fuels, as well as to renewables. Oil and gas resources will not diminish or increase because of climate changes, but climate change impacts may affect access to them. Warmer winters may broaden possibilities of exploitation of oil and gas resources in cold regions like Alaska and Siberia. When it comes to coal, researchers have suggested that "possible increases in frequency and intensity of rainfalls may lead to changes in river/groundwater levels and flooding, which could cause changes in coal quality and coal-handling. This would increase maintenance costs of coal-fired power plants and the operating cost of coal preparing, for example due to the need for on-site drainage. It is important to observe that increased costs in coal-handling and quality may interfere negatively in quantified reservoirs, as it may affect the economic feasibility of its exploration". ${ }^{41}$ But fossil fuels are generally less prone to being affected by climate changes than renewables. As R. Schaeffer et al. point out, "renewable energy can be more vulnerable, due to its dependence to weather and climate". ${ }^{42}$ That vulnerability concerns all renewable energy sources: 1 ) hydropower (the use of which is determined by availability of water resources and the hydrological cycle; possibilities to use hydropower may be reduced in some regions and extended in another); 2 ) wind (with wind speeds defining "not only the economic feasibility of exploiting wind resources but also the reliability of electricity production once the capacity is installed"; it should be emphasized that wind power cannot be stored and "power demand fluctuations may not match natural variations in wind speeds, rendering the operation of wind power more susceptible to changing wind patterns resulting from climate change" - also in this case changes may be positive in some regions and negative in others) ${ }_{i}^{43} 3$ ) sun (it

\footnotetext{
38 R. Nayberg, Qu'est-ce qu'un produit strategique? L'exemple du petrole, Défense nationale 1997, No. 2, after: B. Nowak, Gas Market Liberalization and Energy Security. Legal and Institutional Aspects, Warsaw 2012, p. 98.

39 J.C. Ciscar, P. Dowling, Integrated Assessment..., p. 531.

40 Ibidem, p. 532.

41 R. Schaeffer et al., Energy Sector..., p. 4.

42 Ibidem, p. 2.

43 Ibidem, pp. 2-4.
} 
is generally predicted that the possibilities of using solar energy will improve as a result of climate changes); 4) biomass (the agriculture of energy crops would probably be affected negatively by climate changes resulting in decreased availability of water resources and more frequent occurrence of extreme weather events). Wind and sun are generally deemed as volatile, fluctuating and hard to be predicted accurately in a longer perspective, ${ }^{44}$ even if no climate changes had ever taken place.

Apart from effects on energy resources, climate changes will affect power generation, "in particular thermal (including nuclear) and hydropower stations. Lower rainfall may reduce the water supply available for power plant cooling, thereby affecting plant availability. In extreme cases this could lead to forced outages. Thermal power plants use steam to produce electricity, and the thermodynamic process involved relies heavily on the supply of cooling water (...)."45 In Poland about $70 \%$ of total water consumption is due to its use as a cooling water for energy production. ${ }^{46}$ According to the authors of the Polish National Strategy for Adaptation to Climate Change, diminution of the level of availability of water resources may result in "lower traditional power plants efficiency with open circulation cooling and in reduction in amounts of energy generated by these installations. In gas-steam systems the performance level and power depend additionally on the air temperature used for fuel combustion. With the increasing temperature, the need for air compression increases and thus the efficiency and power of the installation decrease".47

Next to energy production, energy transmission and distribution will also be influenced by climate changes through impacts of weather conditions on the energy infrastructure. As is indicated in the literature, "changes in the frequency and severity of extreme events (e.g. storms, cyclones, hurricanes, floods) could damage energy infrastructure. As climate extremes are likely to increase, the energy system will also require additional spare capacity because a greater proportion of assets risk being unavailable at any given time. Moreover, much existing energy infrastructure (e.g. pipelines, electricity transmission, ports, refineries, gasification terminals, oil and gas platforms) may have been constructed in areas that in the future will no longer be suitable due to climate change induced changes in sea levels, land use and waterways". ${ }^{48}$ It is interesting to analyze anticipations on a national level in that respect. The Polish National Strategy for Adaptation to Climate Change draws the reader's attention to the fact that the "Polish power system is dominated by overhead lines which, unlike cable networks, are highly exposed to failures caused by strong winds and excessive ice build-up. The occurrence of extreme weather events like hurricanes, intense storms, etc. may lead to

\footnotetext{
44 J. Perner, Ch. Riechmann, "Energy Market Design with Capacity Mechanisms" [in:] Capacity Mechanisms in the EU Energy Market. Law, Policy, and Economics, eds L. Hancher, A. de Hauteclocque, M. Sadowska, Oxford 2015, p. 72.

45 J.C. Ciscar, P. Dowling, Integrated Assessment..., p. 532.

46 Polish National Strategy..., p. 25.

47 Ibidem, p. 25.

48 J.C. Ciscar, P. Dowling, Integrated Assessment..., p. 533.
} 
a higher risk of damage to transmission and distribution lines and therefore, to limitations in supply of electricity". ${ }^{49}$

Last, climate changes will definitely affect patterns of energy use and consumption. Obviously, higher temperatures will entail lower demand for heating and higher demand for cooling, but "climate change can also affect (...) electricity demand in industries (...) and (...) electricity (...) demand in agriculture $(. . .)^{\prime 50}$

The aforementioned considerations demonstrate that impacts of climate changes on the energy sector involve all elements of the energy chain, and that that may be affected mainly by temperature rises, alterations in water circulation and extreme weather events. Therefore, adaptation actions in response to such threats should also encompass a wide array of measures, some of which should form the content of legislation. Researchers suggest that adaptation "can be focused on maintaining the essence of the impacted system (incremental adaptation, or resilience), or changing fundamental attributes of the system to respond to the impacts of climate change or its effects (transformational adaptation)".51 Both types of actions are necessary for the adaptation of the energy sector to inevitable climate changes. Definitely, the current legal state and possible legal solutions to the problem of adaptation of the energy sector to climate changes are worth analyzing.

\section{The current legal state concerning the adaptation of the energy sector to climate changes and recommended solutions - de lege lata and de lege ferenda indices}

There are at least a few legal strategies that could be adopted or developed to resolve, maybe not completely, but to a considerable extent, the issue of the adaptation of the energy sector to climate changes. In my opinion, supporting energy efficiency should be treated as an obvious and primary answer, because at the same time it resolves many other problems. At present, the matter is regulated by the directive of $2012{ }^{52}$ which was implemented into the Polish legal order by the Act on energy efficiency. ${ }^{53}$ The need to increase energy efficiency (defined in article 2 point 4) of the directive as "the ratio of output of performance, service, goods or energy, to input of energy") is often treated as an issue of negligible importance, certainly as one that does not attract so much attention as other problems related to the energy sector. ${ }^{54}$ On-going discus-

\footnotetext{
49 Polish National Strategy..., p. 25.

50 R. Schaeffer et al., Energy Sector..., p. 7.

51 R. Biesbroek, A. Lesnikowski, Adaptation..., p. 306.

52 Directive 2012/27/EU of the European Parliament and of the Council of 25 October 2012 on energy efficiency, amending Directives 2009/125/EC and 2010/30/EU and repealing Directives 2004/8/ EC and 2006/32/EC, OJ L 315 of 14.11.2012, p. 1-56, as amended.

53 Act of 20 May 2016 on the energy efficiency, uniform text OJ 2020, item 264, as amended.

54 B. Barton, "The Law of Energy Efficiency" [in:] Beyond The Carbon Economy: Energy Law in Transition, eds D.N. Zillman, C. Redgwell, Y.O. Omorogbe, L.K. Barrera-Hernández, Oxford 2008, p. 67.
} 
sions pertain rather to the growing demand for fossil fuels in the context of a decreasing amount of fossil fuels available for profitable exploitation, and emissions generated by energy production. However, an increase of energy efficiency could solve or at least alleviate all such problems, especially because there is a great potential for such increase in the EU and its Member States. It is therefore justified to perceive energy efficiency as a kind of an energy source. ${ }^{55}$

The directive leaves a wide leeway with regard to the ways of improving energy efficiency, so each Member State could pick its own ways to achieve that goal. From a technical point of view, the pursuit of energy efficiency is often made through undertakings that deliver energy savings. It should be emphasized that actions aimed at energy efficiency are not hampered by any risks resulting from climate change, provide a remedy for climate-related problems of all segments of the energy chain, and - finally - do not interfere negatively with mitigation of climate changes. Actually, energy efficiency supports the latter goal. Moreover, increasing energy efficiency helps reduce all environmental threats posed by the energy sector; therefore it seems to be actually without negative features. The major obstacles appearing here are the ones related to the necessity of constructing an effective measure of support for energy efficiency, ensuring proper incentives for investments for the interested parties. Elaboration of such incentives on the EU level, in addition to or instead of the ones implemented in particular countries, is worth considering.

If we desist from mitigation of climate changes, one could consider further use and increase of use of fossil fuels as one of actions that could be of aid in adaptation. However, bearing in mind the problems with supply, not to mention various harmful effects on the environment, resulting from use of such resources, that solution should be excluded, irrespective of whether we actually aim at greenhouse gases emissions reduction or not. Instead, intensification of exploitation of renewables should be further pursued. Promotion of renewables is regulated by the respective EU directive ${ }^{56}$ and, within the framework of the Polish legal order, by the Act on renewable sources of energy ${ }^{57}$ As in the case of energy efficiency, the law of the European Union provides a large margin of discretion for Member States, since it neither favours any particular type of renewables, nor imposes any specific support systems. In practice, there are various different instruments used in $\mathrm{EU}$ countries in that respect, as a rule linked to the duty of purchasing of a certain amount of energy from renewable sources. Promotion of renewable energy is, above all, deemed to be a means of mitigating climate changes, since although it could also be of use for the purpose of adaptation, renewable sources are, as already mentioned, vulnerable to impacts of climate changes. Therefore, they may be hindered from being used as a measure of adaptation. Such risks may, to some extent, be reduced or even eliminated by the wise choice of kinds

55 B.N. Stram, Key Challenges to Expanding Renewable Energy, Energy Policy 2016, vol. 96, p. 728.

56 Directive (EU) 2018/2001 of the European Parliament and of the Council of 11 December 2018 on the promotion of the use of energy from renewable sources, OJ L 328 of 21.12.2018, p. 82-209.

57 Act of 20 February 2015 on renewable energy sources, uniform text OJ 2020, item 261, as amended. 
of renewables. Photovoltaics and geothermal energy seem to be good examples here; in the case of wind power, hydropower and biomass, one should thoroughly consider whether their efficient use in a given geographical region will not be prevented by the impacts of climate changes. In the case of all renewables, however, adjustments of energy infrastructure are indispensable (see further considerations). Also, a similar obstacle as in the case of pursuing an increase in energy efficiency appears here: the problem of proper shaping of a support system, providing adequate incentives to develop exploitation of renewables.

Renewable energy sources like solar energy are suitable for dispersed energy generation by entities such as prosumers (renewables self-consumers) and energy communities, which is also advocated as one of instruments that could be used for the purpose of adaptation. The directive for the first time provides for some guarantees for prosumers; they should, inter alia, be vested with the right to "generate renewable energy, including for their own consumption, store and sell their excess production of renewable electricity, including through renewables power purchase agreements, electricity suppliers and peer-to-peer trading arrangements, without being subject (...) to discriminatory or disproportionate procedures and charges, and to network charges that are not cost-reflective", as well as to "receive remuneration, including, where applicable, through support schemes, for the self-generated renewable electricity that they feed into the grid, which reflects the market value of that electricity and which may take into account its long-term value to the grid, the environment and society" (article 21.2 of the directive). At present, by virtue of the Polish Act on renewable sources of energy, prosumers in Poland take advantage of the system of mutual settlements (reliefs) and do not bear changeable settlement or distribution fees, instead of the previously applicable system of sale of excess electric energy to the grid. Apart from the question of the efficiency of the current system, since the directive expressly obliges Member States to ensure the right of prosumers to sell the excess energy, that model seems to contravene the directive. Dispersed energy generation by prosumers and energy communities does not affect mitigation negatively, does not per se bring hazards to the environment, and should certainly be qualified as one of solutions that ought to be embodied in practice to the broadest extent possible.

Last but not least, modification and reinforcement of energy infrastructure is an essential set of actions that should be taken to adapt the energy sector to climate changes. These matters are only fragmentarily regulated in the EU law, mainly within the scope related to trans-European energy networks ${ }^{58}$ or the protection of critical infrastructure. ${ }^{59}$ With regard to the latter, researchers observe that "while the initial focus

\footnotetext{
58 Regulation (EU) No 347/2013 of the European Parliament and of the Council of 17 April 2013 on guidelines for trans-European energy infrastructure and repealing Decision No 1364/2006/EC and amending Regulations (EC) No 713/2009, (EC) No 714/2009 and (EC) No 715/2009, OJ L 115 of 25.4.2013, p. 39-75, as amended.

59 Council Directive 2008/114/EC of 8 December 2008 on the identification and designation of European critical infrastructures and the assessment of the need to improve their protection, OJ L 345 of 23.12 .2008$, p. $75-82$.
} 
of the emerging European Critical Infrastructure Protection (CIP) policy was on terrorism as a threat for disruptions, the policy evolved into an all-hazards approach" ${ }^{\prime 60}$ - so at present legal provisions aimed at protection of critical infrastructure may also serve the purposes of adaptation of the energy infrastructure to climate changes. Furthermore, the electricity directive ${ }^{61}$ expressly promotes the introduction of smart grids ${ }^{62}$ and smart metering. ${ }^{63}$ As far as Polish law is concerned, requirements for the construction of energy infrastructure may be found in various legal acts, including, without limitation, the Construction Law. ${ }^{64}$

Smart grids and smart metering not only permit remote metering of use of electricity by consumers, but also integration and coordination of energy supplies from conventional and unconventional sources, including energy generated in a dispersed manner. Such new technologies also permit improvement of energy efficiency and attainment of energy savings. It has also been raised in literature that "new types of infrastructure designs must provide both protection from extreme events now, but also help to integrate renewables into carbon dense areas"..$^{65}$ Even in the event of a failure of the energy network, smart grids may provide enhanced possibilities of identification of failures and relocation of electricity to critical recipients. ${ }^{66}$ Furthermore, in the context of adaptation to climate changes, "a proper designed electricity system is able also to handle all reasonably likely extreme cases without a blackout. Since wind and solar power are volatile energy sources, there need to be backup capacities to secure the energy provision". ${ }^{67}$ Due to the volatility of energy production from the most popular renewables like sun and wind, it is of the utmost importance to provide a complex legal framework for construction and use of energy storage facilities. Only recently have such steps have been taken in Poland. ${ }^{68}$

\footnotetext{
60 D. Rübbelke, S. Vögele, Impacts of Climate Change on European Critical Infrastructures: The Case of the Power Sector, Environmental Science \& Policy 2011, vol. 14, p. 54.

61 Directive (EU) 2019/944 of the European Parliament and of the Council of 5 June 2019 on common rules for the internal market for electricity and amending Directive 2012/27/EU, OJ L 158 of 14.6.2019, p. 125-199.

62 According to article 2 point 7 on guidelines for trans-European energy infrastructure, a smart grid is "an electricity network that can integrate in a cost efficient manner the behaviour and actions of all users connected to it, including generators, consumers and those that both generate and consume, in order to ensure an economically efficient and sustainable power system with low losses and high levels of quality, security of supply and safety".

63 According to article 2 point 23 of the electricity directive, smart metering is "an electronic system that is capable of measuring electricity fed into the grid or electricity consumed from the grid, providing more information than a conventional meter, and that is capable of transmitting and receiving data for information, monitoring and control purposes, using a form of electronic communication".

64 Act of 7 July 1994 - Construction Law, uniform text OJ 2020, item 1333, as amended.

65 K.M. Kelly-Pitou et al., "Microgrids and Resilience: Using a Systems Approach to Achieve Climate Adaptation and Mitigation Goals", The Electricity Journal 2017, vol. 30, p. 26.

66 R. Lyster, "Smart Grids: Opportunities for Climate Change Mitigation and Adaptation", Monash University Law Review 2010, vol. 36, p. 173, after: J. Verschuuren, Legal Aspects..., p. 281.

67 G. Totschnig et al., "Climate Change Impact and Resilience in the Electricity Sector: The Example of Austria and Germany", Energy Policy 2017, vol. 103, p. 247.

68 The Act of 20 May 2021 amending the Energy Law, OJ 2021, item 1093.
} 
Therefore, modification and strengthening of the energy infrastructure may constitute a measure of adaptation itself, but at the same time, it allows or at least contributes to the introduction of another means of adaptation of the energy sector to climate changes, such as the already mentioned support for energy efficiency, intensification of exploitation of renewables, and dispersed energy generation. Moreover, it deals with impacts of climate changes that may be encountered by different elements of the energy chain and does not impede efforts to reduce greenhouse gases emissions.

Apart from some aspects of the transformation of energy infrastructure (like providing a legal framework for construction and functioning of energy storage facilities), the solutions described in this article are not actually a novelty. Currently, most of them are, with miscellaneous results, being introduced or extended, although they are often not perceived as those intended to adapt the energy sector to climate changes, but rather as tools to achieve other environmental goals. Bearing in mind the inevitable character of climate changes and the added value such solutions provide in respect of adaptation of the energy sector, continuous development of those solutions, as soon and as much as possible, is recommended.

\section{Literature}

Agrawala S. et al., "Adapting to Climate Change: Costs, Benefits, and Modelling Approaches", International Review of Environmental and Resource Economics 5/2011.

Barton B., "The Law of Energy Efficiency" [in:] Beyond The Carbon Economy: Energy Law in Transition, eds D. N. Zillman, C. Redgwell, Y.O. Omorogbe, L.K. Barrera-Hernández, Oxford 2008.

Bassett T.J., Fogelman Ch., "Déjà vu or Something New? The Adaptation Concept in the Climate Change Literature", Geoforum 2013, vol. 48.

Biesbroek R., Lesnikowski A., "Adaptation. The Neglected Dimension of Polycentric Climate Governance?" [in:] Governing Climate Change: Polycentricity in Action?, eds A. Jordan et al., Cambridge 2018.

Ciscar J.C., Dowling P., "Integrated Assessment of Climate Impacts and Adaptation in the Energy Sector", Energy Economics 2014, vol. 46.

Fankhauser S., "The Costs of Adaptation", Wiley Interdisciplinary Reviews: Climate Change $1 / 2010$.

Jensen S. et al., "An Introduction to the Green Paradox: The Unintended Consequences of Climate Policies", Review of Environmental Economics and Policy 2015, vol. 9, issue 2.

Kelly-Pitou K.M. et al., "Microgrids and Resilience: Using a Systems Approach to Achieve Climate Adaptation and Mitigation Goals", The Electricity Journal 2017, vol. 30.

Nowak B., Gas Market Liberalization and Energy Security. Legal and Institutional Aspects, Warsaw 2012.

Perner J., Riechmann Ch., "Energy Market Design with Capacity Mechanisms” [in:] Capacity Mechanisms in the EU Energy Market. Law, Policy, and Economics, eds L. Hancher, A. de Hauteclocque, M. Sadowska, Oxford 2015.

Korzeniowski P., Zasady prawne ochrony środowiska, Łódź 2010. 
van der Ploeg F., Withagen C., "Global Warming and the Green Paradox: A Review of Adverse Effects of Climate Policies", Review of Environmental Economics and Policy 2015, vol. 9, issue 2. Rübbelke D., Vögele S., "Impacts of Climate Change on European Critical Infrastructures: The Case of the Power Sector", Environmental Science \& Policy 2011, vol. 14.

Sikora A., "European Green Deal - Legal and Financial Challenges of the Climate Change", ERA Forum 2021, vol. 21.

Schaeffer R. et al., "Energy Sector Vulnerability to Climate Change: A Review", Energy 1/2012.

Stram B.N., "Key Challenges to Expanding Renewable Energy", Energy Policy 2016, vol. 96.

Termini V., "Energy and European Institutions" [in:] The European Union in the 21st century: perspectives from the Lisbon Treaty, eds S. Micossi, G.L. Tosato, Brussels 2009.

Totschnig G. et al., "Climate Change Impact and Resilience in the Electricity Sector: The Example of Austria and Germany", Energy Policy 2017, vol. 103.

Wasilewski A., "Koncepcja zintegrowanej ochrony środowiska w prawie Wspólnoty Europejskiej" [in:] Studia z prawa Unii Europejskiej w piątą rocznicę utworzenia Katedry Prawa Europejskiego Uniwersytetu Jagiellońskiego, ed. S. Biernat, Kraków 2000.

Verschuuren J., "Legal Aspects of Climate Change Adaptation" [in:] Climate Change and the Law, eds E.J. Hollo et al., Dordrecht 2013.

Watkiss P. et al., "The Complementarity and Comparability of Climate Change Adaptation and Climate Change Mitigation", Wiley Interdisciplinary Reviews: Climate Change 6/2015.

\section{Summary}

\section{Ilona Przybojewska}

\section{Adaptation to Climate Changes with Particular Focus on the Legal Environment of the Energy Sector}

Within the legal regime of climate protection, there is a gap between the amount of space and resources devoted to mitigation on the one hand and adaptation to climate changes on the other, clearly to the detriment of the latter. Nevertheless, at least some climate changes seem inevitable and therefore it is certainly necessary to take some adaptation measures. That is especially true in the case of the energy sector, which plays a crucial role in the entire economy. The article deals with legal instruments aimed at adapting the energy sector to climate change. It analyses the general legislative approach to adaptation, the expected negative consequences of climate changes for the energy sector, as well as the current legal regulations in this matter in order to conclude as to the legal instruments that could be useful for the adaptation of the energy sector to climate changes.

Keywords: adaptation; climate changes; energy sector. 


\section{Streszczenie}

\section{Ilona Przybojewska}

\section{Adaptacja do zmian klimatu ze szczególnym uwzględnieniem prawnego otoczenia sektora energetycznego}

W ramach prawnego reżimu ochrony klimatu istnieje rozziew pomiędzy wielkością przestrzeni i środków poświęcanych z jednej strony - mitygacji, z drugiej - adaptacji do zmian klimatycznych, wyraźnie na niekorzyść tej drugiej - chociaż przynajmniej część skutków zmian klimatu wydaje się nieunikniona, a zatem z całą pewnością konieczne jest przedsięwzięcie pewnych działań adaptacyjnych. Jest tak w szczególności w przypadku sektora energetycznego, który pełni kluczową rolę w kontekście całej gospodarki. Niniejszy artykuł dotyczy prawnych instrumentów nakierowanych na dostosowanie sektora energetycznego do zmian klimatycznych. Prowadzona analiza odnosi się do ogólnego podejścia do adaptacji, przewidywanych negatywnych konsekwencji zmian klimatycznych dla sektora energetycznego, jak również obecnych regulacji prawnych w tej kwestii - w celu wyciągnięcia wniosków co do prawnych instrumentów, które mogą być użyteczne w kontekście adaptacji sektora energetycznego do zmian klimatycznych.

Słowa kluczowe: adaptacja; zmiany klimatu; sektor energetyczny. 